\title{
Perilaku sadar gizi dan ketahanan pangan keluarga serta hubungannya dengan status gizi balita di Kabupaten Tanah Laut, Kalimantan Selatan
}

\author{
Rahmadi', Toto Sudargo ${ }^{2}$, Agus Wijanarka ${ }^{3}$
}

\begin{abstract}
Background: Act No. 25/2000 about National Development Program and Vision Healthy Indonesia 2010 specified that $80 \%$ of Indonesian families become nutrition aware families. The result of survey on nutrition aware families in indicated that in 2006 as much as $52.7 \%$ and in 2007 as much as $27.2 \%$ of families were not yet nutrition aware. The result of nutritional status monitoring of underfives (Z-score) showed undernourishment increased from $5.1 \%$ in 2004 to $10.1 \%$ in 2005 .

Objective: To analyze association between nutrition aware behavior and food security of the family and nutrition status of underfives at District of Tanah Laut, Province of Kalimantan Selatan.

Method: The study was observational with cross sectional design. The dependentvariable was nutritional status of underfives (z-score for weight/length); the independent variables were nutrition aware behavior and food security of the family; and the confounding variables were characteristics of the family (parents' education, number of the family members, knowledge of mothers about nutrition and family income). Subject consisted of underfives of 6-24 months with as many as 198 underfives. Data analysis used chi square and double logistic regression (multiple logistic regression) and qualitative analysis with indepth interview for families that were not yet nutrition aware.

Result: There were 145 families (73.2\%) that were nutrition aware and 53 (26.8\%) that were not yet nutrition aware; based on energy consumption $51.1 \%$ of families had enough food and $48.9 \%$ were undernourished; based on protein consumption $52.5 \%$ of families had enough food and $47.5 \%$ were undernourished; and children with good nutrition status were $72.6 \%$ for boys and $72.8 \%$ or girls. There was significant association between nutrition aware behavior and nutrition status of underfives $(p=0.010)$. The result of logistic regression test showed that there was significant association between the number of family members and food security of the family $(p<0.05)$ with $\mathrm{OR}=5.516(95 \% \mathrm{Cl}=2.584-11.775)$. There was significant association between knowledge of mothers about nutrition and food security of the family $(p<0.05)$ with $\mathrm{OR}=0.486(95 \% \mathrm{Cl}=0.25-0.914)$.

Conclusion: There was no association between nutrition aware behavior and food security of the family based on level of energy and protein consumption. There was significant association $(p<0.05)$ between number of family members and food security of the family based on level of energy and protein consumption. There was significant association between knowledge of mothers about nutrition and food security of the family based on energy consumption. There was no association between parents' education and family income based on level of energy and protein consumption. There was significant association between nutrition aware behavior of the family and nutrition status of underfives; however there was no association between food security of the family and nutrition status of underfives.
\end{abstract}

KEYWORDS: nutrition aware, family characteristics, food security, nutritional status of underfives

\begin{abstract}
ABSTRAK
Latar Belakang: Undang-undang nomor 25 tahun 2000 tentang Program Pembangunan Nasional dan Visi Indonesia Sehat 2010 menetapkan 80\% keluarga menjadi keluarga sadar gizi (kadarzi). Hasil data survei kadarzi pada tahun 2006 dan 2007 didapatkan keluarga yang belum kadarzi 52,7\% dan 27,2\%. Hasil pemantauan status gizi balita (z-ScoreBB/U) didapatkan status gizi kurang menunjukkan adanya peningkatan, yaitu tahun 2004 sebesar (5,1\%), tahun 2005 (9,8\%) dan tahun 2006 (10,1\%)

Tujuan: Untuk menganalisis hubungan antara perilaku sadar gizi dan ketahanan pangan keluarga dengan status gizi balita di Kabupaten Tanah Laut Provinsi Kalimantan Selatan.

Metode: Jenis penelitian observasional dengan rancangan cross sectional. Variabel terikat: status gizi balita (z-score BB/TB) dan variabel bebas: perilaku sadar gizi, ketahanan pangan keluarga serta variabel pengganggu: pendidikan orang tua, jumlah anggota keluarga, pengetahuan gizi ibu dan pendapatan keluarga. Subjek penelitian balita usia 6-24
\end{abstract}

${ }^{1}$ Dinas Kesehatan Kabupaten Tanah Laut, Jl. H. Boejasin No. 9 Pelaihari, Provinsi Kalimantan Selatan, e-mail: rahmadi_alabio@yahoo.com 2Prodi Gizi Kesehatan Fakultas Kedokteran Universitas Gadjah Mada, Jl. Farmako, Sekip Utara, Yogyakarta 55281, e-mail.totosud@indosat.net.id 3Prodi Gizi Poltekkes Kemenkes Yogyakarta, Jl. Tata Bumi 3, Banyuraden, Gamping, Sleman, Yogyakarta 55293, e-mail: agusw_jogja@yahoo.co.id 
bulan, jumlah 198 balita. Analisis yang digunakan adalah uji chi-square dan regresi logistik berganda (multiple logistic regression) dan didukung analisis kualitatitf dengan indepth interview bagi keluarga belum kadarzi.

Hasil: Keluarga sudah kadarzi 145 (73,2\%) dan belum kadarzi 53 (26,8\%). Indikator kadarzi tentang dukungan keluarga memberikan ASI eksklusif 0-6 bulan paling banyak tidak dilaksanakan. Alasannya adalah setelah melahirkan ASI tidak keluar, susu ibu bengkak dan mengeluarkan darah, hamil lagi, dan alasan pekerjaan. Semua keluarga menggunakan garam beryodium dalam memasak makanan. Keluarga tahan pangan dan tidak tahan pangan berdasarkan tingkat konsumsi energi masing-masing sebesar $47,5 \%$ dan 52,5\%, keluarga yang tahan pangan dan tidak tahan pangan berdasarkan tingkat konsumsi protein masing-masing sebesar 52,5\% dan 47,5\% dan status gizi balita hasil z-score BB/TB didapatkan balita gizi baik $72,7 \%$ dan gizi kurang 27,3\%. Perilaku sadar gizi berhubungan signifikan dengan ketahanan pangan keluarga berdasarkan tingkat konsumsi energi $(p<0,05)$. Perilaku sadar gizi dan ketahanan pangan keluarga berdasarkan tingkat konsumsi energi dan protein tidak berhubungan signifikan dengan status gizi balita $(p>0,05)$.

Kesimpulan: Perilaku sadar gizi, jumlah anggota keluarga, pengetahuan gizi ibu dan pendapatan per kapita berhubungan signifikan dengan ketahanan pangan keluarga berdasarkan tingkat konsumsi energi, sedangan pengetahuan gizi ibu dan pendapatan per kapita berhubungan signifikan dengan ketahanan pangan keluarga berdasarkan tingkat konsumsi protein. Perilaku sadar gizi keluarga dan ketahanan pangan keluarga berdasarkan tingkat konsumsi energi dan protein tidak berhubungan dengan status gizi balita (z-score BB/TB).

KATA KUNCI: keluarga sadar gizi, karakteritik keluarga, ketahanan pangan, status gizi balita

\section{PENDAHULUAN}

Keluarga sadar gizi (kadarzi) adalah cerminan keluarga yang berperilaku gizi seimbang, yang ditandai dengan sikap dan perilaku gizi yang mendukung terciptanya keadaan gizi yang optimal bagi anggota keluarganya. Undang-undang Nomor 25 tahun 2000 tentang Program Pembangunan Nasional (propenas) dan di dalam Visi Indonesia Sehat 2010 ditetapkan bahwa 80\% keluarga menjadi kadarzi karena keluarga mempunyai nilai yang sangat strategis dan menjadi inti dalam pembangunan seluruh masyarakat, serta menjadi tumpuan dalam pembangunan manusia seutuhnya(1).

Konsumsi pangan dengan gizi yang cukup dan seimbang merupakan salah satu faktor penting yang menentukan tingkat kesehatan dan intelegensia manusia. Tingkat kecukupan konsumsi pangan dan gizi seseorang akan mempengaruhi keseimbangan perkembangan jasmani dan rohani yang bersangkutan.Untuk mempertahankan ketahanan pangan tingkat rumah tangga, ditetapkan rekomendasi kecukupan energi dan protein per orang/ hari adalah 2.200 kilokalori dan 52 gram (2).

Hasil analisis data survei kadarzi di Kabupaten Tanah Laut tahun 2006 didapatkan sebanyak 422 KK (kepala keluarga) $(52,75 \%)$ belum kadarzi dan yang kadarzi sebesar $378 \mathrm{KK}(47,25 \%)$. Tahun 2007, di antara $4.720 \mathrm{KK}$ yang disurvei, ternyata sebesar $3.436 \mathrm{KK}(72,8 \%)$ telah kadarzi dan sebesar $1.284 \mathrm{KK}(27,2 \%)$ belum kadarzi. Hal ini berarti dari tahun 2006 sampai 2007 Kabupaten Tanah Laut belum mencapai target kadarzi sebesar $80 \%$, tetapi trennya membaik. Indikator paling banyak yang belum dipraktikkan adalah ibu melahirkan belum memberikan ASI eksklusif sampai bayi usia 6 bulan. Hasil pemantauan konsumsi gizi (PKG) tahun 2006, di antara 1.859 rumah tangga (RT) yang dipantau menunjukkan sebanyak $933 \mathrm{RT}(50,2 \%)$ dengan tingkat konsumsi energi
(TKE) $<80 \%$ angka kecukupan gizi yang dianjurkan (AKG) dan sebesar $618 \mathrm{RT}(33,24 \%)$ dengan tingkat konsumsi protein (TKP) $<80 \%$ AKG. Hasil pemantauan status gizi (PSG) berat badan menurut umur (BB/U) menunjukkan adanya peningkatan dari tahun 2004-2006 dengan presentase tiap tahun yaitu pada tahun $2004(5,1 \%)$, tahun $2005(9,8 \%)$ dan tahun 2006 sebesar 10,1\%. Hasil data PSG tahun 2006 terhadap 3.839 balita berdasarkan tinggi badan menurut umur (TB/U) didapatkan sebesar $9,1 \%$ balita sangat pendek dan sebesar $12,8 \%$ balitanya pendek. Berdasarkan berat badan menurut tinggi badan (BB/TB), balita kurus sekali dan kurus masing-masing sebesar 2,9\%dan 5,6\%.

Golongan rawan gizi terutama bayi dan anak balita. Kekurangan energi dan protein yang kronis pada bayi dan anak-anak dapat menyebabkan pertumbuhan dan perkembangan terganggu. Salah satu dampak serius yang dapat terjadi dari permasalahan ini adalah tumbuhnya anak-anak yang mempunyai tingkat kecerdasan terhambat dan mengakibatkan retardasi mental yang tak dapat diperbaiki kembali karena kekurangan gizi, sehingga perlu perhatian khusus (3). Tujuan penelitian ini adalah untuk menganalisis hubungan antara perilaku sadar gizi dan ketahanan pangan keluarga dengan status gizi balita di Kabupaten Tanah Laut Provinsi Kalimantan Selatan.

\section{BAHAN DAN METODE}

Jenis penelitian ini adalah observasional dengan rancangan cross sectional (potong lintang) untuk mengetahui hubungan variabel bebas dengan variabel terikat. Penelitian ini menggunakan metode kuantitatif sebagai metode utama dan data kualitatif digunakan sebagai data penunjang.Teknik pengambilan sampel dari tiga puskesmas (Puskesmas Pelaihari, Takisung, dan Kurau) dilakukan secara stratified random sampling dengan jenis proporsional-sampel 
sebanding dengan jumlah populasi. Memilih anggota sampel dari setiap desa dengan rumus perhitungan jumlah sampel bantuan teknik penarikan sampel systematic atau sistematis (4). Subjek penelitian yaitu balita yang berada dalam wilayah kerja Puskesmas Pelaihari, Puskesmas Takisung, dan Puskesmas Kuraudi Kabupaten Tanah Laut dengan jumlah balita198.

Data dikumpulkan peneliti dan dibantu oleh enumerator yang meliputi data primer yaitu data karakteristik keluarga seperti pendidikan orang tua, jumlah anggota keluarga, pengetahuan gizi ibu, dan pendapatan per kapita/bulan yang diketahui dari total pengeluaran pangan dan nonpangan, data perilaku sadar gizi, data ketahanan pangan keluarga, dan status gizi balita. Data sekunder meliputi data jumlah balita usia 6-24 bulan yang diperoleh dari puskesmas. Analisis data dilakukan secara bertahap, yaitu analisis univariat, bivariat dengan uji statistikChiSquare dan multivariat menggunakan uji regresi logistik berganda (multiple logistic regression) untuk mengetahui variabel yang paling dominan berpengaruh terhadap ketahanan pangan keluarga berdasarkan tingkat konsumsi energi dan protein.

\section{HASIL DAN BAHASAN}

\section{Karakteristik keluarga dan sampel}

Jumlah responden yang tidak bekerja lebih besar dibandingkan yang bekerja, masing-masing sebesar $140(70,7 \%)$ dan $58(29,3 \%)$ responden. Di antara 140 responden yang bekerja, didapatkan 19 responden $(9,6 \%)$ bekerja sebagai petani dan sisanya bekerja sebagai PNS, pegawai swasta, buruh, dan wiraswata. Seluruh KK memiliki pekerjaan dengan persentase paling besar adalah petani/nelayan $(34,8 \%)$, sisanya pekerja swasta $(22,7 \%)$, buruh (19,2\%), wiraswasta (15,7\%) dan PNS/ABRI $(7,6 \%)$. Jumlah anggota keluarga responden berkisar antara 3-7 orang, sebagian besar $142(71,7 \%)$ dikategorikan sebagai keluarga kecil (tiga sampai 4 orang anggota) dan sisanya $56(28,3 \%)$ adalah keluarga besar (>4 orang). Rata-rata jumlah anggota keluarga sebesar 3 orang.

Tingkat pendapatan keluarga berkisar antara $\mathrm{Rp}$ $831.000,-$ sampai $\mathrm{Rp} 3.727 .750$,- dengan rata-rataRp 1.411.000,-. Nilai median pendapatan per kapita/bulan adalah Rp 348.000,-. Rata-rata pendapatan per kapita/bulan penduduk di Kabupaten Tanah Laut yaitu Rp 605.575,-Hal ini berarti rata-rata pendapatan per kapita/bulan hasil penelitian masih di bawah ketetapan yang ada. Pengetahuan responden tentang gizi dan makanan, termasuk pengetahuan tentang kadarzi ternyata sudah cukup baik. Hasil penelitian menunjukkan persentase paling besar tingkat pengetahuan responden $(61,1 \%)$ berada pada kategori tinggi dan 38,9\% lainnya berada pada kategori rendah.

Umur balita yang terbanyak pada penelitian ini 12-24 bulan yaitu $128(64,6 \%)$ orang, umur 6 sampai <12 bulan sebesar $70(35,4 \%)$ orang, dan sebagian balita berjenis kelamin laki-laki yaitu $106(53,5 \%)$ orang. Bila status gizi balita dilihat dari hasil Z-score BB/TB didapatkan sebagian besar balita atau $72,7 \%$ balita dengan stutus gizi baik, sisanya $27,3 \%$ balita termasuk gizi kurang.

\section{Perilaku sadar gizi dan ketahanan pangan keluarga}

Perilaku sadar gizi. Keluarga yang sudah sadar gizi lebih besar jumlahnya dibandingkan dengan keluarga yang belum sadar gizi, masing-masing sebesar 145 (73,2\%) dan $53(26,8 \%)$. Hal ini berarti angka kadarzi masih di bawah target nasional sebesar 80\% (Gambar 1).
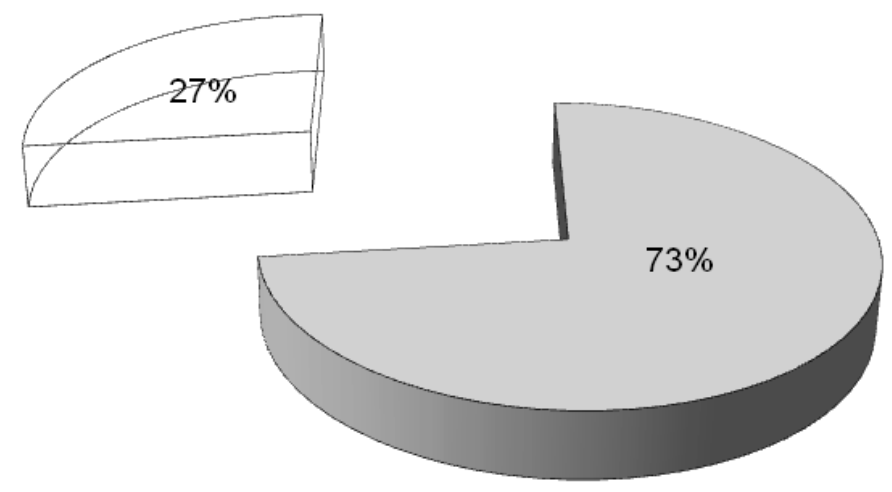

$$
\text { 口sudah kadarzi } \quad \square \text { belum kadarzi }
$$

Gambar 1. Perilaku sadar gizi yang dilakukan keluarga

Rendahnya keluarga yang belum kadarzi sebagian besar disebabkan responden tidak memberikan ASI eksklusif sejak usia 0-6 bulan. Bermacam-macam alasan yang diungkapkan responden sehingga tidak memberikan ASI kepada bayinya, seperti: setelah melahirkan ASI tidak keluar sehingga diberikan susu formula/susu botol, payudara ibu yang bengkak dan mengeluarkan darah ketika dihisap bayi, hamil lagi, dan alasan pekerjaan. Selain itu, ada responden yang beranggapan bahwa ASI eksklusif hanya diberikan usia 0-4 bulan. Hal ini kemungkinan responden masih terpaku pada indikator kadarzi yang sebelumnya bahwa ASI eksklusif diberikan sejak usia 0-4 bulan, padahal indikator kadarzi yang diberlakukan adalah 0-6 bulan. Suatu penelitian menyatakan beberapa faktor yang berhubungan dengan keberhasilan pemberian ASI eksklusif yaitu adanya pelayanan rawat gabung, pemberian penyuluhan mengenai ASI oleh petugas kesehatan, dukungan suami, dan dukungan anggota lain yang terlibat dalam pengasuhan bayi (5). Penelitian lain juga menyatakan bahwa terdapat hubungan yang signifikan antara pengetahuan dan dukungan suami terhadap perilaku kadarzi terutama yang berkaitan dengan kebiasaan memantau status gizi, menggunakan garam beryodium, dan pemberian ASI eksklusif (6). Terdapatnya keluarga yang belum kadarzi juga disebabkan pemberian 
dua kapsul vitamin A dosis tinggi ketika masa nifas yang belum dikonsumsi secara optimal. Untuk menanggulangi hal ini, hendaknya dinas kesehatan dan puskesmas di KabupatenTanah Laut lebih fokus melakukan peningkatan sosialisasi program kadarzi kepada masyarakat, terutama yang berhubungan dengan peningkatan pemberian ASI eksklusif sejak bayi lahir sampai usia 6 bulan dan pemberian kapsul vitamin A dosis tinggi pada ibu nifas.

Ketahanan pangan keluarga. Keluarga yang tidak tahan pangan berdasarkan tingkat konsumsi energi jumlahnya lebih besar dibandingkan keluarga yang tahan pangan berdasarkan tingkat konsumsi energi, masing-masing sebesar 104 (52,5\%) dan 94 (47,5\%) (Gambar 2).
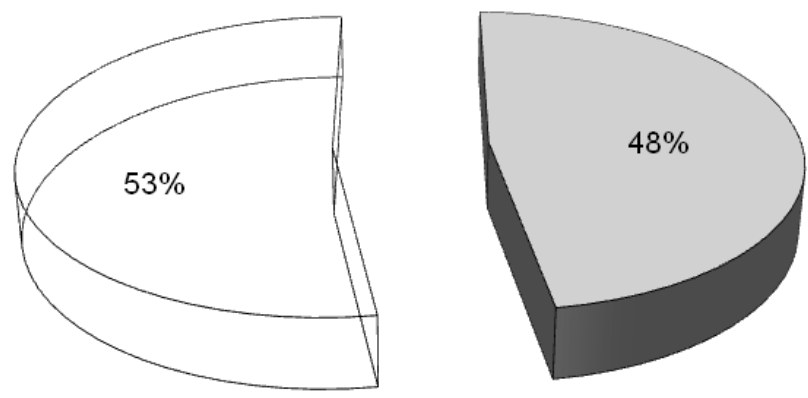

口tahan pangan $>80 \%$ AKE $\square$ tidak tahan pangan $\leq 80 \%$ AKE

\section{Gambar 2. Ketahanan pangan keluarga berdasarkan tingkat konsumsi energi}

Ketahanan pangan keluarga berdasarkan angka kecukupan protein didapatkan keluarga yang tahan pangan jumlahnya lebih besar dibandingkan keluarga yang tidak tahan pangan, masing-masing sebesar $104(52,5 \%)$ dan 94 (47,5\%) (Gambar 3).
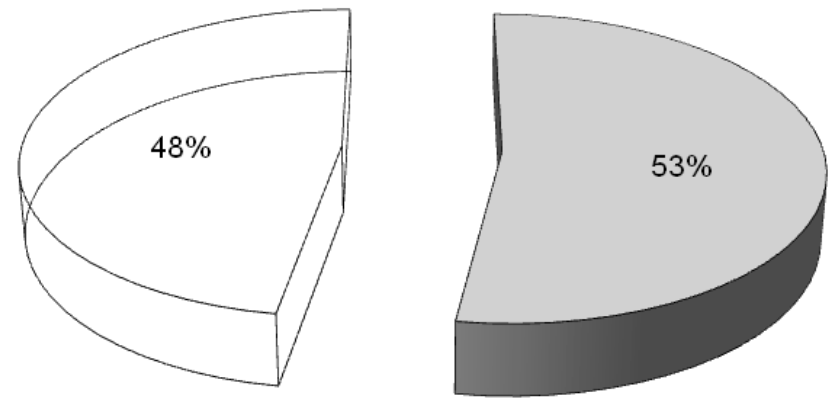

口tahan pangan $>80 \%$ AKP $\quad$ tidak tahan pangan $\leq 80 \%$ AKP

\section{Gambar 3. Ketahanan pangan keluarga berdasarkan tingkat konsumsi protein}

Kurang pangan dan rawan pangan pada beberapa keluarga terjadi jika keluarga atau rumah tangga mengalami ketidakcukupan pangan untuk memenuhi standar kebutuhan fisiologis bagi pertumbuhan dan kesehatan anggota keluarga. Secara agregat, bila dilihat dari kecukupan konsumsi energi dan pangsa pengeluaran pangan keluarga yang tergolong tahan pangan dan kurang pangan pada penelitian ini sebesar 75 (37,9\%) dan 92 (46,5\%). Proporsi keluarga yang rentan pangan dan rawan pangan adalah $9,5 \%$ dan $6,1 \%$. Selanjutnya bila dilihat dari kecukupan konsumsi protein dan pangsa pengeluaran pangan keluarga, yang tergolong tahan pangan dan kurang pangan pada penelitian ini sebesar $85(42,9 \%)$ dan $80(40,4 \%)$, dan proporsi keluarga yang rentan pangan dan rawan pangan adalah $9,6 \%$ dan $7,1 \%$. Namun demikian, dilihat dari hasil wawancara dengan responden yang belum kadarzi dapat diketahui bahwa ternyata responden memiliki pengetahuan yang cukup baik mengenai ketahanan pangan dalam keluarga.

Berdasarkan hasil pengukuran derajat ketahanan pangan, dapat diidentifikasi bahwa terdapat keluarga yang kurang pangan, rentan pangan, maupun rawan pangan di tingkat keluarga. Mengingat sumberdaya pembangunan yang dimiliki pemerintah Kabupaten Tanah Laut relatif terbatas, maka diharapkan partisipasi dan kepedulian dari seluruh komponen masyarakat dalam upaya peningkatan ketahanan pangan keluarga. Selain itu, untuk mengefektifkan sumberdaya yang terbatas, maka penentuan kelompok sasaran peningkatan ketahanan pangan agar intervensi penanganan keluarga yang rawan pangan, rentan pangan, dan kurang pangan menjadi tepat dalam operasionalnya.

Intervensi bagi kelompok keluarga kurang atau tidak tahan pangan diprioritaskan pada upaya penyadaran dan peningkatan pengetahuan pangan dan gizi. Untuk kelompok keluarga rentan pangan yang secara ekonomi kurang, intervensi lebih diprioritaskan pada upaya peningkatan pendapatan agar dapat mengakses pangan sumber protein, vitamin, dan mineral (gizi beragam dan seimbang). Sementara itu, untuk kelompok keluarga rawan pangan, dalam jangka pendek diperlukan bantuan pangan misalnya program beras murah untuk keluarga miskin, disertai bimbingan peningkatan dan pemanfaatan sumberdaya keluarga untuk meningkatkan pendapatan, daya beli, dan akses terhadap pangan.

\section{Hubungan antara perilaku sadar gizi dengan ketahanan pangan keluarga berdasarkan tingkat konsumsi energi dan protein}

Data tabulasi silang antara perilaku sadar gizi dan ketahanan pangan keluarga berdasarkan tingkat konsumsi energi dan protein menunjukkan bahwa persentase keluarga yang sudah kadarzi lebih besar untuk tahan pangan (>80\% AKG). Hasil analisis statistik menunjukkan ada hubungan signifikan antara perilaku sadar gizi dan ketahanan pangan keluarga berdasarkan tingkat konsumsi energi. Hubungan yang signifikan inidapat dipengaruhi oleh seseorang yang akan melakukan kadarzi apabila 
ia tahu tujuan dan manfaat bagi kesehatan apabila tidak melakukan kadarzi. Setelah seseorang mengetahui kadarzi atau sesuatu objek yang diperoleh dari pengamalan, orang tua, guru, teman, buku-buku, media-media informasi lain, kemudian mengadakan penilaian yang selanjutnya dipersepsikan dalam sikap. Selanjutnya, diharapkan orang tersebut akan melaksanakan atau berperilaku sesuai dengan apa yang diketahuinya. Banyak faktor yang turut mendukung terjadinya perilaku kadarzi dalam keluarga. Pengetahuan suami tentang kadarzi yang tinggi dan sikap suami tentang kadarzi yang kuat akan menjadi motivator terjadinya perilaku kadarzi dalam keluarga, juga didukung oleh pendidikan dan aktivitas istri (6).

Hasil analisis statistik menunjukkan bahwa tidak ada hubungan signifikan antara perilaku sadar gizi dan ketahanan pangan keluarga berdasarkan tingkat konsumsi protein. Tidak adanya hubungan ini dapat disebabkan kondisi ketahanan pangan tidak saja ditentukan oleh perilaku sadar gizi keluarga, tetapi ada beberapa hal yang dapat mempengaruhinya. Sebuah penelitian mengemukakan bahwa ketahanan pangan keluarga dapat ditentukan dari berbagai aspek, yaitu aspek manajemen, ketersediaan pangan, distribusi pangan, dan konsumsi pangan. Terdapat kaitan yang erat antara tingkat keadaan gizi dengan konsumsi pangan, sehingga semakin baik konsumsi pangan seseorang, akan semakin baik pula keadaan gizinya (7).

\section{Hubungan perilaku sadar gizi dengan status gizi balita}

Masalah gizi yang terjadi di tingkat keluarga erat kaitannya dengan perilaku keluarga, yang tidak hanya disebabkan oleh kemiskinan dan ketersediaan pangan. Kebersamaan antarkeluarga dapat memobilisasi masyarakat untuk memperbaiki keadaan gizi dan kesehatan. Semakin baiknya perubahan perilaku gizi anggota keluarga diharapkan akan diikuti dengan semakin meningkatnya status gizi anggota keluarga terutama balita. Tabel 1 memperlihatkan hubungan antara perilaku sadar gizi dan status gizi balita (Z-score BB/TB).

Hasil penelitian didapatkan bahwa diantara 144 balita berstatus gizi baik (Z-score BB/TB), terdapat 111 $(76,6 \%)$ keluarga yang sudah kadarzi dan $33(62,3 \%)$ keluarga belum kadarzi, sedangkan di antara 54 balita berstatus gizi kurang didapatkan $34(23,4 \%)$ pada keluarga yang sudah kadarzi dan sebesar $20(37,7 \%)$ keluarga yang belum kadarzi.
Setelah dianalisis secara statistik didapatkan nilai $p>0,05$. Hal ini berarti tidak ada hubungan yang signifikan antara perilaku sadar gizi dengan status gizi balita (Z-score BB/TB). Nilai OR sebesar 1,979 menunjukkan bahwa bagi keluarga yang berperilaku kadarzi mempunyai peluang memiliki balita dengan status gizi baik (Z-score BB/TB) sebesar 1,979 kali dibandingkan keluarga yang belum kadarzi.

Hubungan yang tidak signifikan diduga disebabkan oleh timbulnya gizi kurang yang tidak hanya disebabkan asupan makanan yang kurang, tetapi adanya penyakit infeksi. Anak yang mendapat cukup makanan tetapi sering sakit, pada akhirnya dapat menderita gizi kurang. Hal ini bisa terjadi sebaliknya, pada anak yang tidak memperoleh cukup makanan, maka daya tahan tubuhnya akan melemah dan akan mudah terserang penyakit. Sikap dan perilaku hidup sehat dengan kesadaran gizi yang tinggi dari anggota keluarga merupakan bagian dari perbaikan gizi masyarakat. Selain itu, minimnya pengetahuan soal gizi dari beberapa anggota keluarga dan rendahnya pendidikan serta faktor kemiskinan dan ekonomi keluarga juga sangat mempengaruhi konsumsi makanan yang pada akhirnya berpengaruh terhadap keadaan gizi balita. Tingkat pengetahuan gizi seseorang berpengaruh terhadap sikap dan perilaku dalam pemilihan makanan dan konsumsi pangan keluarga, yang pada akhirnya akan berpengaruh pada keadaan gizi individu dan anggota keluarga. Semakin tinggi pengetahuan gizi ibu diharapkan memperbaiki ketahanan pangan di keluarga. Pengetahuan ibu mengenai bahan makanan yang aman dan bergizi sangat diperlukan untuk melaksanakan tugas-tugas tersebut. Suatu penelitian menyatakan bahwa status gizi anak dengan ukuran BB/TB dipengaruhi oleh konsumsi energi, ketahanan keluarga dan perkembangan anak (8).

\section{Hubungan antara ketahanan pangan keluarga berdasarkan tingkat konsumsi energi dan protein dengan status gizi balita (Z-score BB/TB)}

Terdapat kaitan erat antara tingkat keadaan gizi dengan konsumsi pangan. Keragaman konsumsi pangan berpengaruh terhadap keadaan gizi anak balita. Hasil penelitian menunjukkan bahwa persentase ketahanan pangan keluarga berdasarkan tingkat konsumsi energi dan protein yang makin baik, akan semakin baik pula status gizi balita, demikian pula sebaliknya.Setelah dianalisis secara statistik, tidak ada hubungan yang signifikan antara ketahanan pangan keluarga berdasarkan tingkat konsumsi energi dan protein dengan status gizi balita $(p>0,05)$.

Tabel 1. Hubungan perilaku sadar gizi dengan status gizi balita (Z-score BB/TB)

\begin{tabular}{|c|c|c|c|c|c|c|c|}
\hline \multirow{3}{*}{ Perilaku sadar gizi } & \multicolumn{4}{|c|}{ Status gizi balita (BB/TB) } & \multirow{3}{*}{ Total } & \multirow{3}{*}{$\mathbf{p}$} & \multirow{3}{*}{ OR } \\
\hline & \multicolumn{2}{|c|}{ Baik } & \multicolumn{2}{|c|}{ Kurang } & & & \\
\hline & $\mathbf{n}$ & $\%$ & $\mathbf{n}$ & $\%$ & & & \\
\hline Kadarzi & 111 & 76,6 & 34 & 23,4 & 145 & 0069 & 1979 \\
\hline Belum kadarzi & 33 & 62,3 & 20 & 37,7 & 53 & 0,069 & $1,9 / 9$ \\
\hline
\end{tabular}


Tidak adanya hubungan antara ketahanan pangan keluarga berdasarkan tingkat konsumsi energi dan protein dengan status gizi balita, kemungkinan disebabkan adanya faktor-faktor yang mempengaruhi konsumsi pangan dalam keluarga, seperti faktor ekonomi dan faktor nonekonomi. Faktor nonekonomi tersebut yaitu besar keluarga, pendidikan ibu rumah tangga, dan pekerjaannya. Hasil penelitian mengemukakan bahwa jumlah anggota diduga turut menentukan tingkat konsumsi makanan. Jumlah anggota keluarga yang besar bila tidak diimbangi dengan peningkatan pendapatan akan memperburuk status gizi keluarga secara keseluruhan (9).

Penelitian lain mengemukakan bahwa masukan energi dan zat gizi mempengaruhi keadaan gizi dan pertumbuhan anak. Energi dan protein sangat berperan terhadap tumbuh kembang anak (10). Terdapat hubungan yang nyata antara konsumsi energi dan protein dalam perkembangan motorik kasar anak. Selanjutnya penelitian lain juga menemukan adanya hubungan yang bermakna antara asupan makanan (energi dan protein) dengan status gizi balita (11). Demikian pula ada yang menyatakan penyebab utama gagal tumbuh anak adalah penyakit infeksi dan rendahnya konsumsi makanan padat energi (12).

Konsumsi pangan atau makanan dipengaruhi pula oleh pandangan serta nilai-nilai yang berlaku di masyarakat, seperti keputusan yang harus dibuat bila nilai yang satu lebih tinggi dari yang lain, seperti mementingkan bendabenda materi daripada makanan. Hal ini membuktikan bahwa tidak selamanya peningkatan ekonomi akan meningkatkan konsumsi makanan. Setelah kebutuhan materi tersebut terpenuhi, keluarga akan memperhatikan kebutuhan makanan. Hubungannya dengan kekurangan gizi, distribusi makanan di dalam keluarga juga memegang peran penting. Adanya distribusi makanan yang tidak proporsional dapat merugikan anak, yang berpengaruh terhadap status gizi anak. Oleh sebab itu anak yang kurang gizi biasanya tersebar tidak hanya pada keluarga miskin, tetapi dapat juga terjadi pada keluarga mampu.

Cara yang dapat dilakukan untuk meningkatkan ketahanan pangan keluarga, selain akses secara fisik dan ekonomi, juga diperlukan akses informasi. Oleh karena itu, perlu dilakukan penyebaran informasi tentang nilai gizi bahan makanan, keamanan pangan, teknik pengolahan bahan makanan, dan teknik penyajian makanan kepada segenap lapisan masyarakat melalui berbagai media, seperti radio, koran lokal yang terdapat di daerah dan leaflet. Khusus bagi keluarga miskin, untuk usaha pencegahan terjadinya KEP, bentuk intervensi utama yang dilakukan adalah usaha meningkatkan pendapatan mereka, seperti pengadaan lapangan kerja baik bagi bapak/ suami maupun ibu/ isteri. Selain itu, kegiatan yang dapat dilakukan adalah dengan operasi pasar bahan pokok terutama beras dan minyak goreng dengan harga murahdan padat karya.
Uji regresi logistik antara perilaku sadar gizi, jumlah anggota keluarga, pengetahuan gizi ibu, dan pendapatan per kapita dengan ketahanan pangan keluarga berdasarkan tingkat konsumsi energi dan protein

Analisis multivariat dilakukan untuk menganalisis hubungan beberapa variabel bebas dengan satu variabel terikat. Variabel bebas yang layak dimasukkan dalam analisis multivariat adalah perilaku sadar gizi, jumlah anggota keluarga, pengetahuan gizi ibu dan pendapatan per kapita karena pada analisis bivariat mempunyai nilai $p<0,25$. Hasil uji regresi logistik antara perilaku sadar gizi, jumlah anggota keluarga, pengetahuan gizi ibu dan pendapatan per kapita dengan ketahanan pangan keluarga berdasarkan tingkat konsumsi energi dapat dilihat pada Tabel 2.

Hasil uji statistik (Tabel 2) menunjukkan bahwa perilaku sadar gizi, jumlah anggota keluarga, pengetahuan gizi ibu,dan pendapatan per kapita berhubungan secara signifikan dengan ketahanan pangan keluarga berdasarkan tingkat konsumsi energi $(p<0,05)$.Variabel perilaku sadar gizi merupakan variabel yang paling dominan berpengaruh terhadap ketahanan pangan keluarga berdasarkan tingkat konsumsi energi karena mempunyai nilai OR yang tertinggi, yaitu sebesar 0,435 . Keluarga yang berperilaku kadarzi dalam praktik sehari-hari memiliki peluang sebesar 0,435 kali untuk tahan pangan ( $>80 \%$ AKG) berdasarkan tingkat konsumsi energi dibandingkan keluarga tidak tahan pangan ( $\leq 80 \% \mathrm{AKG}$ ) berdasarkan tingkat konsumsi energi. Rendahnya nilai OR diduga karena adanya faktorfaktor lain yang sangat berpengaruh terhadap ketahanan pangan keluarga berdasarkan tingkat konsumsi energi.

Hasil uji regresi logistik antara pengetahuan gizi ibu dan pendapatan per kapita dengan ketahanan pangan

Tabel 2. Hasil uji regresi logistik hubungan antara perilaku sadar gizi, jumlah anggota keluarga, pengetahuan gizi ibu, dan pendapatan per kapita dengan ketahanan pangan keluarga berdasarkan tingkat konsumsi energi

\begin{tabular}{lcccc}
\hline \multirow{2}{*}{ Variabel } & \multirow{2}{*}{ Sig } & \multirow{2}{*}{ OR } & \multicolumn{2}{c}{ 95\% Cl } \\
\cline { 4 - 5 } & & & Lower & Upper \\
\hline Perilaku sadar gizi & $0,027^{*}$ & 0,435 & 0,211 & 0,909 \\
Jumlah anggota keluarga & $0,001^{*}$ & 0,252 & 0,113 & 0,563 \\
Pengetahuan gizi ibu & $0,007^{*}$ & 0,405 & 0,210 & 0,782 \\
Pendapatan per kapita & $0,010^{*}$ & 0,419 & 0,217 & 0,810 \\
\hline
\end{tabular}

* Signifikan $(p<0,05)$

Tabel 3. Hasil uji regresi logistik hubungan antara pengetahuan gizi ibu dan pendapatan per kapita dengan ketahanan pangan keluarga berdasarkan tingkat konsumsi protein

\begin{tabular}{lcccc}
\hline \multirow{2}{*}{ Variabel } & \multirow{2}{*}{ Sig } & \multirow{2}{*}{ OR } & \multicolumn{2}{c}{$95 \%$ Cl } \\
\cline { 4 - 5 } & & & Lower & Upper \\
\hline Pengetahuan gizi ibu & $0,045^{*}$ & 0,551 & 0,307 & 0,987 \\
Pendapatan per kapita & $0,035^{*}$ & 0,541 & 0,305 & 0,959 \\
\hline
\end{tabular}

*Signifikan $(p<0,05)$ 
keluarga berdasarkan tingkat konsumsi protein dapat dilihat pada Tabel 3.

Hasil uji statistik yang terlihat pada Tabel 3 menunjukkan bahwa pengetahuan gizi ibu dan pendapatan per kapita berhubungan secara signifikan dengan ketahanan pangan keluarga berdasarkan tingkat konsumsi protein $(p<0,05)$. Variabel pengetahuan gizi ibu merupakan variabel yang paling dominan berpengaruh terhadap ketahanan pangan keluarga berdasarkan tingkat konsumsi protein karena mempunyai nilai OR yang tertinggi, yaitu sebesar 0,551 . Keluarga yang memiliki ibu dengan pengetahuan gizi yang baik memiliki peluang sebesar 0,551 kali untuk tahan pangan ( $>80 \%$ AKG) berdasarkan tingkat konsumsi protein dibandingkan keluarga tidak tahan pangan ( $\leq 80 \% \mathrm{AKG})$ berdasarkan tingkat konsumsi protein.

Berdasarkan nilai OR yang hanya sebesar 0,435 dan 0,551 , dapat diduga kemungkinan adanya penyebab lain yang lebih besar mempengaruhi ketahanan pangan keluarga berdasarkan tingkat konsumsi energi dan protein, misalnya penyakit infeksi.Sebuah penelitian menyatakan penyakit infeksi dapat berpengaruh terhadap daya tahan tubuh anak karena penyakit dapat menurunkan nafsu makan sehingga konsumsi makan menurun. Anak yang terkena penyakit infeksi yang berulang dan kronis akan mengalam igangguan gizi, sehingga pertumbuhan anak secara antropometri terganggu, yang akhirnya anak menjadi kurus bahkan dapat menyebabkan kematian (13).

Status gizi yang optimal akan tercapai bila keseimbangan antara asupan zat-zat gizi dengan kebutuhan tubuh akan zat gizi terpenuhi, sehingga akan mendukung pertumbuhan dan perkembangan yang optimal, serta kemampuan beraktivitas. Keadaan gizi dipengaruhi oleh kemampuan menyediakan pangan (kuantitas dan kualitas) dan asuhan gizi ibu pada anak. Asuhan gizi anak dipengaruhi oleh faktor pendidikan, perilaku, serta keadaan kesehatan anggota keluarga.

Kajian penelitian tentang kadarzi, kerawanan pangan dan gizi telah banyak dilakukan, demikian pula programprogram yang dilaksanakan terutama untuk mencegah dan menanggulangi rawan pangan seperti pemetaan kadarzi, pemantauan konsumsi gizi, pemantauan status gizi, dan program usaha perbaikan gizi keluarga. Program-program tersebut sebaiknya dilakukan secara berkelanjutan sehingga mampu mengatasi persoalan pangan dan gizi di tingkat keluarga atau masyarakat. Selain itu, yang perlu mendapat perhatian adalah pentingnya pemahaman bahwa pemecahan masalah rawan pangan dan gizi serta kemiskinan tidak dapat hanya ditangani oleh sektor kesehatan atau pertanian saja, walaupun jumlah penduduk miskin, rawan pangan dan gizi umumnya terdapat di desa. Upaya pemantapan ketahanan pangan atau rawan pangan dan penanggulangan kemiskinan memerlukan kerjasama, koordinasi, dan sinergitas dari berbagai instansi terkait, lembaga swadaya masyarakat, swasta, dan partisipasi aktif masyarakat setempat.

Kelemahan penelitian adalah tidak mempertimbangkan salah satu faktor langsung dan tidak langsung yang berhubungan dengan status gizi balita seperti penyakit infeksi yang diderita dan pola asuh anak. Selain itu, faktor yang berhubungan langsung dengan ketahanan pangan seperti ketersediaan pangan juga tidak diteliti. Penelitian ini tidak menggunakan standar WHO-2005 tetapi menggunakan standar WHO-NCHS. Alasan tidak digunakannya standar WHO-2005 karena selama ini di Kabupaten Tanah Laut masih menerapkan penggunaan baku rujukan WHO-NCHS baik dalam hal perencanaan dan pelaksanaan program upaya perbaikan gizi masyarakat.

Selain itu kelemahan yang lain adalah kelemahan desain penelitian dan ukuran keragaman konsumsi pangan. Hal ini karena besarnya pendapatanyang didapatkan oleh keluarga berpendapatan tinggi cenderung lebih rendah dari yang sebenarnya karena mereka ingin mengurangi atau menghindari pajak dan pada keluarga yang pendapatan rendah. Hal yang sama juga terjadi karena mereka cenderung mengabaikan hutang-hutang. Untuk menghindari terjadinya bias yang besar perlu adanya perbaikan kuesioner pendapatan keluarga terutama pengeluaran nonpangan.

Meski memiliki kelemahan, hasil penelitian ini sejalan dengan dugaan bahwa ada hubungan antara perilaku sadar gizi dengan status gizi balita dan jumlah anggota keluarga dan pengetahuan gizi ibu berhubungan dengan ketahanan pangan keluarga. Data kuantitatif yang ada pada penelitian ini didukung data kualitatif hasil wawancara dengan keluarga yang belum kadarzi. Data kuantitatif dari hasil penelitian ini juga didukung oleh data kualitatif.

\section{KESIMPULAN DAN SARAN}

Hasil analisis multivariat perilaku sadar gizi, jumlah anggota keluarga, pengetahuan gizi ibu, dan pendapatan per kapita berhubungan secara signifikan dengan ketahanan pangan keluarga berdasarkan tingkat konsumsi energi, sedangkan pengetahuan gizi ibu dan pendapatan per kapita berhubungan secara signifikan dengan ketahanan pangan keluarga berdasarkan tingkat konsumsi protein. Perilaku sadar gizi keluarga dan ketahanan pangan keluarga (tingkat konsumsi energi dan protein) tidak berhubungan signifikan dengan status gizi balita (Z-score BB/TB).

Saran yang dapat diajukan kepada dinas kesehatan dan puskesmas yaitu pertama, hendaknya lebih fokus melakukan peningkatan sosialisasi program kadarzi kepada masyarakat terutama yang berhubungan dengan 
peningkatan pemberian ASI eksklusif sejak bayi lahir sampai usia 6 bulan dan pemberian kapsul vitamin $A$ pada ibu nifas; kedua, perlu melakukan identifikasi dan pemetaan wilayah berdasarkan derajat ketahanan pangan sampai ke tingkat desa. Hal ini penting untuk menetapkan prioritas dan fokus sasaran intervensi kebijakan pangan dan gizi dalam upaya pemantapan ketahanan pangan keluarga. Mengingat penyebab terjadinya kurang pangan, rentan pangan, maupun rawan pangan berbeda,maka intervensiyang diperlukan juga berbeda; ketiga, untuk meningkatkan ketahanan pangan di tingkat keluarga, selain akses secara fisik dan ekonomi juga diperlukan akses informasi. Oleh karena itu, perlu dilakukan penyebaran informasi yang lebih intensif tentang nilai gizi bahan makanan, keamanan pangan, teknik pengolahan bahan makanan, dan teknik penyajian makanan kepada segenap lapisan masyarakat melalui berbagai media, seperti radio dan koran lokal yang terdapat di daerah dan leaflet.

Bagi peneliti lain yang ingin meneliti pendapatan keluarga, sebaiknya perlu melakukan perbaikan desain penelitian tentang pengumpulan data pendapatan keluarga yang dihitung menurut pengeluaran pangan dan nonpangan, terutama kuesioner nonpangan untuk dicantumkannya item hutang. Hal ini dilakukan untuk menghindari terjadinya bias yang lebih besar.

\section{UCAPAN TERIMA KASIH}

Peneliti mengucapkan terima kasih kepada Bupati Tanah Laut, Kepala Dinas Kesehatan, dan Kepala BKD Kabupaten Tanah Laut serta jajarannya atas dukungan terhadap penelitian ini. Terima kasih juga disampaikan kepada Kepala dan TPG Puskesmas Pelaihari, Takisung, dan Kurau di Kabupaten Tanah Laut atas peran aktif yang diberikan dalam pelaksanaan penelitian ini.

\section{RUJUKAN}

1. Depkes RI. Panduan umum keluarga sadar gizi (kadarzi). Jakarta: Direktorat Jenderal Bina Kesehatan Masyarakat; 2002.

2. ApriyantonoA. Revitalisasi pertahanan dan pemantapan ketahanan pangan rumah tangga. Dewan Pimpinan Pusat Persatuan Ahli Gizi Indonesia (PERSAGI): Prosiding Temu IImiah, Kongres PERSAGI XIII dan Festival Gizi, November 20-24, 2005, Grand Inna, Bali Beach, Sanur-Bali; 2005.

3. Suhardjo. Sosio budaya gizi. Bogor: Departemen Pendidikan dan Kebudayaan Direktorat Jenderal
Pendidikan Tinggi Pusat Antar Universitas Pangan dan Gizilnstitut Pertanian Bogor; 1989.

4. Prasetyo B, Jannah LM. Metode penelitian kuantitatif teori dan aplikasi. Jakarta: Rajagrafindo Persada; 2008.

5. Zulfayani, Julita M, Helmiyati S. Pengaruh dukungan pelayanan kesehatan terhadap pemberian ASI eksklusif pada bayi sampai usia 4 bulan di Kota Pekanbaru. Jurnal Gizi Klinik Indonesia 2005; 2 (2): 53-9.

6. Misbakhudin, Sudargo T, Jamil MD. Pengetahuan dan sikap suami berhubungan dengan perilaku keluarga mandiri sadar gizi (kadarzi) di Kota Bandung Provinsi Jawa Barat. Gizi Klinik Indonesia 2008; 5 (1):28-35.

7. Lembaga IImu Pengetahuan Indonesia (LIPI). Kebijakan ketahanan pangan nasional. Jakarta: Pusat Pusat Dokumentasi dan Informasi IImiah Media Informasi IImu Pengetahuan dan Teknologi 2007;5 (2).

8. Sunarti E. Analisis faktor risiko status gizi anak [serial online]. Jakarta: Widyakarya Nasional Pangan dan Gizi; 2008 [Diakses 17 Maret 2009]. Tersedia dalam: http:// wkpg.org.

9. Jamal S. Karakteristik gizi masyarakat pedesaan dan perkotaan. Pusat Penelitian dan Pengembangan Farmasi Badan Penelitiandan Pengembangan Kesehatan Departemen Kesehatan RI. Jakarta: Cermin Dunia Kedokteran 1997; (114).

10. Kartika V, Prihatini S, Syafrudin, Jahari AB. Pola pemberian makan anak (6-18 bulan) dan hubungannya dengan pertumbuhan dan perkembangan anak pada keluarga miskin dan tidak miskin. Bogor: Departemen Kesehatan RI Badan Penelitian dan Pengembangan Kesehatan. Penelitian Gizi dan Makanan (Food and Nutrition Research) 2000; 37-47.

11. Aritonang I, Priharsiwi E. Revitalisasi pertahanan dan pemantapan ketahanan pangan rumah tangga. Dewan Pimpinan Pusat Persatuan Ahli Gizi Indonesia (PERSAGI): Prosiding Temu Ilmiah, Kongres PERSAGI XIII dan Festival Gizi, November 20-24, 2005, Grand Inna, Bali Beach, Sanur-Bali2005; 284-8.

12. Atmarita, Tilden RL, Nur NN, Ghani A, Widjajanto RM. Status gizi anak Indonesia 1989-2005 dan faktor resiko terpenting. Info Ristek 2007; 5(2).

13. Kartika V, Jahari AB. Studi Dampak Pemberian Makanan Pendamping Air Susu Ibu (MP-ASI) Terhadap Tingkat Pertumbuhan Anak Umur 5 Bulan. Bogor: Departemen Kesehatan RI Badan Penelitian dan Pengembangan Kesehatan. Penelitian Gizi dan Makanan (Food and Nutrition Research) 2003; 26 (1):1-10. 